\title{
Removal of Pathogens from Domestic Wastewater Using Small-Scale Gradual Hydroponics Planted with Duranta erecta, Addis Ababa, Ethiopia
}

\author{
Solomon Tibebu $\mathbb{D}^{1,2,3}$ Abebe Worku, ${ }^{1,2}$ and Kenatu Angassa ${ }^{1,2}$ \\ ${ }^{1}$ Department of Environmental Engineering, College of Biological and Chemical Engineering, \\ Addis Ababa Science and Technology University, Addis Ababa 16417, Ethiopia \\ ${ }^{2}$ Sustainable Energy Center of Excellence, Addis Ababa Science and Technology University, Addis Ababa 16417, Ethiopia \\ ${ }^{3}$ Bioprocess and Biotechnology Center of Excellence, Addis Ababa Science and Technology University, \\ Addis Ababa 16417, Ethiopia \\ Correspondence should be addressed to Solomon Tibebu; solomon.tibebu@aastu.edu.et
}

Received 6 August 2021; Revised 14 December 2021; Accepted 20 December 2021; Published 5 January 2022

Academic Editor: Carla Patrícia Silva

Copyright (c) 2022 Solomon Tibebu et al. This is an open access article distributed under the Creative Commons Attribution License, which permits unrestricted use, distribution, and reproduction in any medium, provided the original work is properly cited.

\begin{abstract}
This study aimed to evaluate the treatment potential of gradual hydroponics planted with Duranta erecta in the removal of pathogens from domestic wastewater. Two experimental and control units were configured in series. Each unit contains three bioreactors and was arranged in a cascaded configuration. The two experimental units used both plant and media, but the two control units used only media to treat the wastewater. Gravel and polyester sponge were used as media. Experimental unit 1 and control unit 1 used gravel as media; however, experimental unit 2 and control unit 2 used polyester sponges as media. The experiment was operated at hydraulic retention times of $1,3,5$, and 7 days in a continuous mode. The performance of the hydroponic system was evaluated by characterizing the influent and effluent quality using standard methods. At optimum hydraulic retention time (7 days), the average removal of experimental units 1 and 2 was $98.7 \%$ and $89.8 \%$ for heterotrophic bacteria, $96.2 \%$ and $86.8 \%$ for total coliform, and $92.9 \%$ and $84.0 \%$ for fecal coliform, respectively. Analysis of variance showed that there was a significant difference $(P<0.05)$ between the two experimental and control units in removing pathogens, but no significant difference $(P>0.05)$ was observed between the two experimental units and between the two control units. Heterotrophic bacteria and coliforms were satisfactorily removed from domestic wastewater via a gradual hydroponic system. Hence, the hydroponic treatment system planted with Duranta erecta has a promising potential in the removal of pathogens from domestic wastewater in developing countries including Ethiopia.
\end{abstract}

\section{Introduction}

Domestic wastewater disposal has become a serious problem in urban areas of developing countries [1]. A large portion of wastewater is discharged directly into nearby surface water bodies or informal drainage channels, often without or with little treatment, especially in developing countries including Ethiopia [2,3]. Globally, surface water quality is rapidly becoming a scarce resource; on the other hand, surface water quality such as river water quality is anthropologically being affected [4-8]. In Addis Ababa, rivers such as Fanta and
Akaki rivers have been impaired for many years due to anthropological activities. Because of an increasing population, urban farming, industrial expansion, and lack of sufficient sewage treatment, the city of Addis Ababa is suffering from serious surface water pollution [9-12].

Wastewater and refuse disposal is often the most intractable sanitation problem in places of detention [13]. The wastewater generated from the Kilinto Prison camp, which is one of the federal prisons located on the outskirts of Addis Ababa, is being directly discharged into a small river called the Fanta River. At the time of this study, $264 \mathrm{~m}^{3} / \mathrm{d}$ of 
untreated effluent is being discharged to the Fanta River, which is located upstream of Big Akaki River. Big Akaki River is one of the most polluted rivers in Addis Ababa $[12,14-16]$. There are many reasons for the pollution of this river, among which is the contamination of its tributaries including the Fanta River. The Fanta River is contaminated by untreated wastewater discharges and runoff from residential settlements in its upstream catchment. Thus, the major sources of pollution in the Fanta River are residential districts and predominantly public institutional facilities that impose environmental burdens. In vegetables, grown by the river water in the studied areas, fecal coliforms and a high colony of E. coli were identified. This might cause an increase in nonspecific diarrhea for consumers, exceeding 104 per $100 \mathrm{ml}$ [17]. The farmers are often exposed to protozoa, which raise the risk of amoebiasis; for example, direct contact with irrigation water polluted with wastewater triggers skin irritations such as dermatitis $[18,19]$. Indicator organisms (coliforms) were used to detect the presence of pathogens [20-22].

Nature-based wastewater treatment and reuse concepts are growing as a naturally focused low-cost wastewater treatment and reuse technology, where wastewater is treated biologically including constructed wetland and hydroponic technology [23]. Determining the source and type of wastewater is very important to determine its characteristics, which in turn helps to select technology and treat the given wastewater properly [24].

Hydroponics is one of the recent wastewater treatment technologies that uses a symbiotic relationship between plants and microorganisms to treat wastewater $[25,26]$. It is the growing of plants in a liquid nutrient solution or wastewater with or without the use of media [27-29]. The plants diffuse oxygen through the rhizosphere and provide surface area for the attachment of microorganisms through their roots [30]. The microbes attached to the plant root will fix nutrients and degrade organic matter so that the plant can absorb them [31]. Hydroponic wastewater treatment technology has the potential to remove microorganisms from wastewater satisfactorily [32]. An aggregate hydroponic system was employed to enhance the growth of microorganisms by providing more surface area for the attachment in addition to the surface area provided by the plant root [30]. Sedimentation, filtration, predation by other organisms, natural die-off, and the release of root exudates are some of the main mechanisms for bacteria removal in aggregate hydroponics [32-34]. Hydroponics has many advantages over conventional and other nonconventional wastewater treatment technologies. Most conventional wastewater treatment technologies have high investment costs. They also have high operational and maintenance costs, and most nonconventional wastewater treatment technologies require large areas [27]. Hydroponic wastewater treatment technologies have relatively low operational and maintenance costs; therefore, they are preferable for developing countries including Ethiopia [35].

Ornamental plants are very important in environmental management and beautification [36]. There are many ornamental plants in Ethiopia such as Nerium oleander, Pinus patula, Euphorbia cotinifolia, Cordyline terminalis, and Duranta erecta [37]. In this study, a hydroponic system planted with Duranta erecta was designed, arranged, and operated to assess the removal potential of pathogens from domestic wastewater. Duranta erecta is the most frequently used ornamental plant in Ethiopia. It is a fast-growing and multistemmed shrub plant. It grows in tropical and warm subtropical regions and suits for gardens. In areas that have infertile natural conditions and drought, they tend to grow up to $1 \mathrm{~m}$, and in watered and fertilized areas, they grow up to $3 \mathrm{~m}$. Duranta erecta has a moderate growth rate, usually $0.5 \mathrm{~m} /$ year for the first few years. They can live for at least 15 years [38]. Hence, the plant is available and suitable to grow hydroponically for assessing its wastewater treatment potential.

There are few studies regarding the use of gradual hydroponics for wastewater treatment [39]. It is also noted that no other study has been carried out regarding the use of Duranta erecta in hydroponic wastewater treatment technology for the removal of pathogens. Therefore, this study aimed to evaluate the treatment potential of gradual hydroponics planted with Duranta erecta in the removal of pathogens from domestic wastewater. The technology needs further researches to be utilized as an alternative decentralized wastewater treatment mechanism for developing countries including Ethiopia.

\section{Materials and Methods}

2.1. Description of the Study Area. The experimental site is located in Akaki Kality sub-city, Addis Ababa, Ethiopia, as shown in Figure 1. The city is located at " $9^{\circ} 02^{\prime} 01.76^{\prime \prime} \mathrm{N}$ and $38^{\circ} 45^{\prime} 18.33^{\prime \prime} \mathrm{E}^{\prime \prime}$ and has an altitude of $2300 \mathrm{~m}$. It has an average temperature, rainfall, and relative humidity of $15.9^{\circ} \mathrm{C}, 1089 \mathrm{~mm}$, and $60.7 \%$, respectively.

\subsection{Experimental Design and Operation of the Hydroponic} System. Two experimental and two control units were configured in series as shown in Figure 2. Each experimental and control unit contained three bioreactors. Each of these units was employed to treat $60 \mathrm{~L}$ wastewater at a given hydraulic retention time (HRT).

Where $\mathrm{A}, \mathrm{B}$, and $\mathrm{C}$ denote bioreactors in experimental unit 1 (E-1); D, E, and F denote bioreactors in control unit 1 (C-1); G, H, and I denote bioreactors in experimental unit 2 (E-2); J, K, and L denote bioreactors in control unit 2 (C-2); RT denotes the reservoir tank; and V, W, X, Y, and Z are sampling ports.

In E-1 and C-1, gravel was used as media, but in E-2 and $\mathrm{C}-2$, a polyester sponge was used as media. Healthy and young plants were collected from Afincho Ber area in Addis Ababa near the experimentation site. The root of the plants was carefully washed to remove the adhered soil material. The plant's root had been trimmed to $11 \mathrm{~cm}$, and five young plants were planted per reactor in E-1 and E-2. On each reactor lid, a forestry tube was used to suspend the plant along with the media. $387.28 \mathrm{~g}$ of sharp gravel, which has a diameter of $1 \mathrm{~cm}$, is placed in each forestry tubes on both E-1 


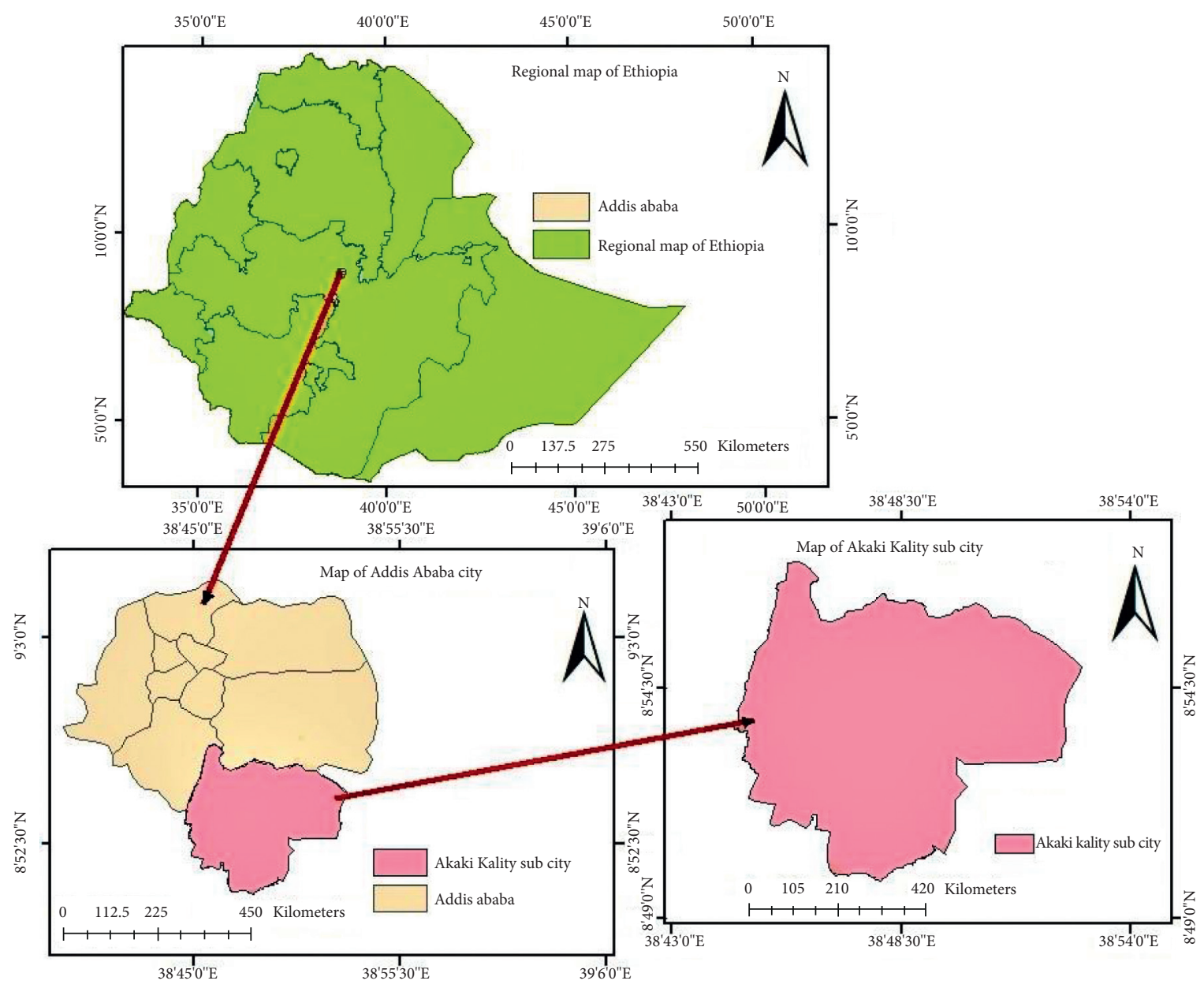

Figure 1: Experimental site.

and C-1. 29.28 g of a polyester sponge is placed in each forestry tubes on both E-2 and C-2. The porosity of gravel and polyester sponge is 0.44 and 0.68 , respectively. The experimental units contain both media and plants, but the control units only contain media.

After planting, acclimatization was conducted for about three months to adapt to the stress of the plants due to high organic loadings [40]. First, tap water was used and then wastewater concentration was increased to $5 \%, 15 \%, 20 \%$, $30 \%, 50 \%, 80 \%$, and finally, 100\% was achieved. Pollutant load increment is conducted every eight days of interval. The untreated wastewater was collected from the direct discharge point of Kilinto Federal Prison camp, transported, and fed to the reservoir tank. The same raw wastewater sample sourced from the reservoir tank was fed to all treatment and control units in a continuous mode. The experiment was operated at four HRTs, i.e., 1, 3, 5, and 7 days [41]. A $6 \mathrm{~mm}$ tap valve was used to control the flow of the wastewater from the reservoir tank (RT) and from each experimental and control bioreactor.

2.3. Wastewater Sampling and Analysis. Four composite samples (one sample per month) were taken from the direct discharge point of Kilinto Prison camp to characterize raw wastewater. Grab sampling was used to collect samples from the influents and effluents of the hydroponic treatment system to evaluate the performance of the treatment system in terms of the removal of pathogens. For each HRT (i.e., 1, 3,5 , and 7 days), one sample was taken from influent and four samples were taken from effluents (i.e., E-1, E-2, C-1, and C-2). A triplicate water sample analysis was conducted according to standard methods. Totally, 20 triplicate sample analyses were conducted according to [42] standard methods for the examination of water and wastewater to evaluate the performance of the experimental and control units. Spread Plate Method 9215 was used to analyze heterotrophic bacteria, and Membrane Filter Method 9222 was used to analyze both total and fecal coliforms.

2.4. Data Analysis. The generated data were analyzed by Microsoft Excel 2013. One-way analysis of variance (ANOVA) was used to compare the treatment performance of hydroponic units for the heterotrophic bacteria, total coliform, and fecal coliform removal with a $95 \%$ confidence interval. A linear correlation was also observed to determine the correlation between HRT and removal efficiency. The removal efficiency was calculated based on the following equation: 


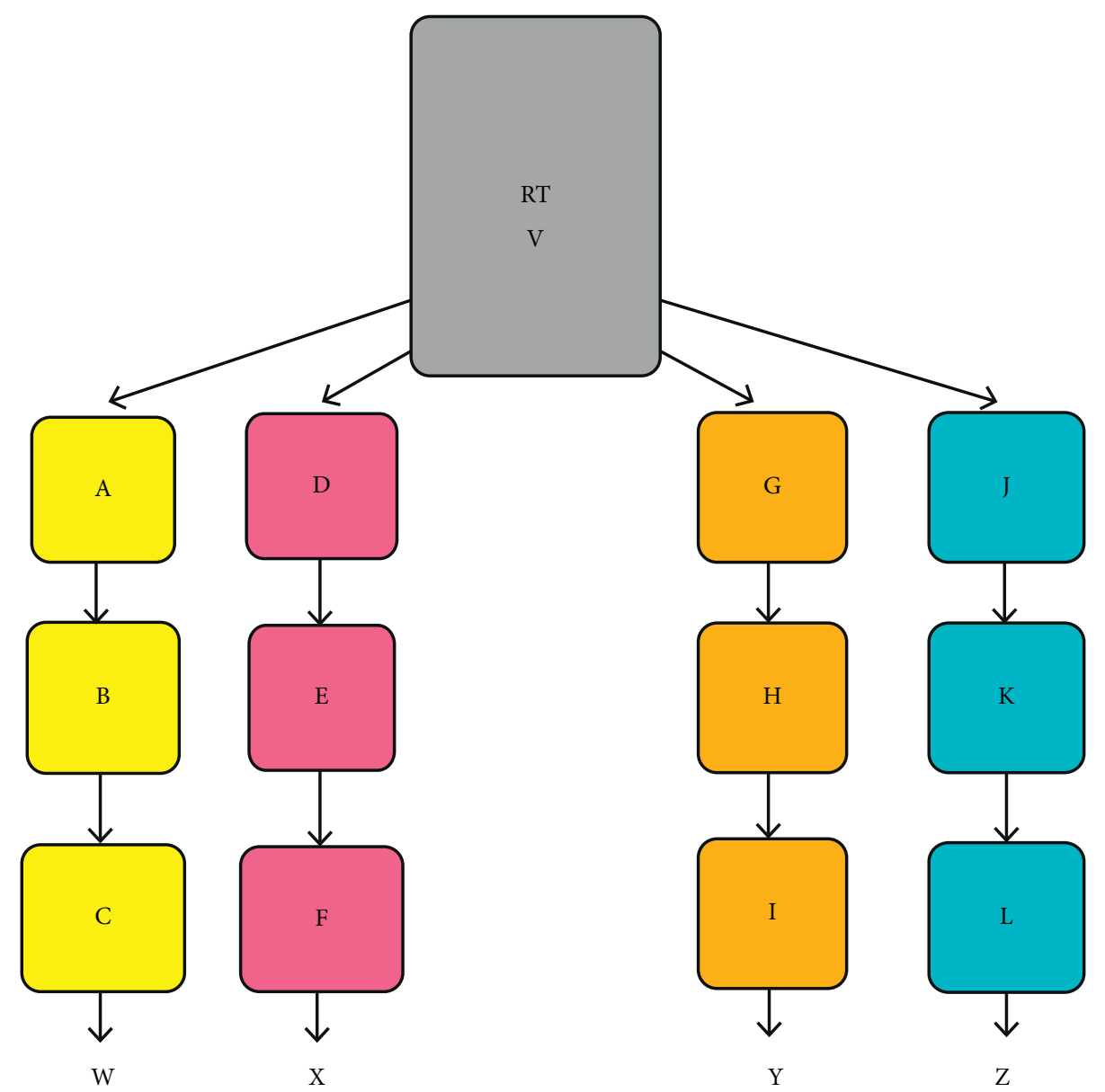

FIgURE 2: Schematic diagram of the experimental setup.

$$
\eta=\left(\frac{C 1-C 2}{C 1}\right) * 100
$$

where $\eta$ is removal efficiency, $c_{1}$ is influent concentration, and $c_{2}$ is effluent concentration.

\section{Results and Discussion}

3.1. Characteristics of the Wastewater. The Kilinto Prison camp wastewater was characterized from August 2019 to November 2019. The average (Avg) heterotrophic bacteria (HB), total coliform (TC), and fecal coliform (FC) counts (log 10 units) in the effluent ranged from 7.94 to $8.63 \mathrm{CFU/}$ $100 \mathrm{ml}, 5.70$ to $5.89 \mathrm{CFU} / 100 \mathrm{ml}$, and 4.37 to $5.14 \mathrm{CFU} /$ $100 \mathrm{ml}$, respectively, as shown in Table 1.

It can be noted that the colony of bacteria is increasing from August to November as can be seen in Table 1. This might be due to the change in climatic conditions and runoff dilution of the effluent in the sewerage system through leaky joints. These factors cause a decrease in bacterial colonies in the two Ethiopian wet seasons (August and September). However, in October and November, the rainfall intensity decreased. This in turn decreased the dilution and increased the pollutant load, which leads to the increment of the bacterial population.

The presence of high coliforms in the effluent indicates the presence of pathogenic organisms that can cause health
TABLe 1: Bacteriological characteristics of Kilinto Prison camp wastewater.

\begin{tabular}{lcccc}
\hline Parameter & $\begin{array}{c}\text { August } \\
\text { Avg } \pm \text { SD }^{*}\end{array}$ & $\begin{array}{c}\text { September } \\
\text { Avg } \pm \text { SD }\end{array}$ & $\begin{array}{c}\text { October } \\
\text { Avg } \pm \text { SD }\end{array}$ & $\begin{array}{c}\text { November } \\
\text { Avg } \pm \text { SD }\end{array}$ \\
\hline HB (CFU/ & $7.94 \pm 0.057$ & $8.63 \pm 0.156$ & $8.40 \pm 0.019$ & $8.35 \pm 0.014$ \\
$100 \mathrm{ml})$ & & & & \\
TC $(\mathrm{CFU} /$ & $5.72 \pm 0.004$ & $5.70 \pm 0.017$ & $5.89 \pm 0.004$ & $5.73 \pm 0.007$ \\
$100 \mathrm{ml})$ & & & & \\
FC (CFU/ & $4.37 \pm 0.102$ & $5.14 \pm 0.079$ & $4.39 \pm 0.081$ & $4.46 \pm 0.099$ \\
$100 \mathrm{ml})$ & & & & \\
\hline
\end{tabular}

*Standard deviation.

effects on humans [43]. Dysentery, cholera, typhoid, fever, and diarrhea are some of the potential health risks, which might be caused by these pathogenic microorganisms in untreated or poorly treated domestic wastewater including the case of this study [44-46]. Therefore, treating such wastewater types containing pathogenic microorganisms before discharge into the environment is mandatory.

3.2. Performance of Gradual Hydroponics. The mean influent value of $\mathrm{HB}, \mathrm{TC}$, and $\mathrm{FC}$ counts (log 10 units) during the experiment varied between $8.76 \pm 0.020$ and $8.95 \pm 0.016 \mathrm{CFU} /$ $100 \mathrm{ml}, \quad 5.54 \pm 0.005$ and $5.86 \pm 0.002 \mathrm{CFU} / 100 \mathrm{ml}$, and $4.55 \pm 0.020$ and $4.96 \pm 0.008 \mathrm{CFU} / 100 \mathrm{ml}$, respectively. At 1, 3, 
5, and 7 days of HRT, the mean effluent concentration of $\mathrm{HB}$, TC, and FC counts ( $\log 10$ units) during the experiment varied between $7.06 \pm 0.098$ and $8.34 \pm 0.004 \mathrm{CFU} / 100 \mathrm{ml}, 4.43 \pm 0.128$ and $5.17 \pm 0.021 \mathrm{CFU} / 100 \mathrm{ml}$, and $3.80 \pm 0.125$ and $4.25 \pm 0.047 \mathrm{CFU} / 100 \mathrm{ml}$, respectively, for E- 1 . For E-2, the mean effluent concentration of $\mathrm{HB}, \mathrm{TC}$, and FC counts (log 10 units) for the same HRT varied between $8.43 \pm 0.005$ and $7.96 \pm 0.015 \mathrm{CFU} / 100 \mathrm{ml}, 5.25 \pm 0.018$ and $4.99 \pm 0.019 \mathrm{CFU} /$ $100 \mathrm{ml}$, and $4.34 \pm 0.032$ and $4.17 \pm 0.046 \mathrm{CFU} / 100 \mathrm{ml}$, respectively. Similarly, At 1, 3, 5, and 7 days of HRT, the mean effluent concentration of HB, TC, and FC counts ( $\log 10$ units) during the experiment varied between $8.63 \pm 0.003$ and $8.38 \pm 0.007 \mathrm{CFU} / 100 \mathrm{ml}, 5.46 \pm 0.011$ and $5.55 \pm 0.008 \mathrm{CFU} /$ $100 \mathrm{ml}$, and $4.47 \pm 0.031$ and $4.68 \pm 0.013 \mathrm{CFU} / 100 \mathrm{ml}$, respectively, for C-1. For C-2, the mean effluent concentration of $\mathrm{HB}, \mathrm{TC}$, and FC counts (log 10 units) for the same HRT varied between $8.68 \pm 0.003$ and $8.56 \pm 0.004 \mathrm{CFU} / 100 \mathrm{ml}, 5.49 \pm 0.012$ and $5.68 \pm 0.007 \mathrm{CFU} / 100 \mathrm{ml}$, and $4.50 \pm 0.030$ and $4.79 \pm 0.011 \mathrm{CFU} / 100 \mathrm{ml}$, respectively. The mean concentration of influent and effluent from each experimental unit and control unit is described in Table 2.

A reduction in the concentration of $\mathrm{HB}, \mathrm{TC}$, and $\mathrm{FC}$ in effluents was observed than that of influents in all experimental and control units. E-1 showed higher performance in removing $\mathrm{HB}, \mathrm{TC}$, and $\mathrm{FC}$ followed by $\mathrm{E}-2, \mathrm{C}-1$, and $\mathrm{C}-2$, respectively, in all applied HRTs. The removal of all three parameters in E-1 and E-2 might be caused by sedimentation, predation by other organisms, and natural die-off [32]. The release of root exudates might also play a vital role in the removal of microorganisms by being toxic to pathogenic microbes [33]. Root exudates are released when the root cell senses the presence of pathogenic microorganisms. The change in the physicochemical environment due to the release of root exudates might also contribute to the removal of pathogenic microorganisms [47]. The removal of all three parameters in C-1 and C-2 might be caused by sedimentation, adsorption, predation by other organisms, and natural die-off. $\mathrm{C}-1$ showed better performance in removing the above three parameters than that of C-2. This might be because of the better provision of adsorption site for the particles, which in turn leads to a better provision of attachment site for the microbes by gravel than the polyester sponge. When particles are removed from the given wastewater, microbes will also be removed because microbes are attached to the particle. Because of this reason, the removal of bacteria in C-1 was enhanced by sedimentation and adsorption of particles. Some studies such as [48] stated that the main removal mechanisms of coliforms are predation by other organisms and physicochemical conditions. However, in this study, experimental units, which were planted with Duranta erecta, showed better bacteria removal efficiency than unplanted control units. This indicates that the main bacteria removal mechanism is the presence of the plants and their species. Some studies such as [49] support the fact that the presence of plants can play a vital role in bacteria removal. Table 3 shows the variance between different groups.

According to Table 3 , no significant difference $(P>0.05)$ was observed between the two experimental units (E-1 and $\mathrm{E}-2)$ and between the two control units (C-1 and C-2).
However, a significant difference $(P<0.05)$ was observed between the two experimental and control units (E-1 and $\mathrm{C}-1$ and $\mathrm{E}-2$ and C-2). The removal performance of the hydroponics in removing $\mathrm{HB}, \mathrm{TC}$, and $\mathrm{FC}$ ranged between 62.4 and $98.7 \%, 57.14$ and $96.21 \%, 48.7$ and $92.9 \%$, respectively, for E-1 and 54.1 and $89.8 \%, 49.14$ and $86.75 \%$, 37.99 and $84.01 \%$, respectively, for E-2 at HRT of $1,3,5$, and 7 days. Similarly, the HB, TC, and FC removal performance of hydroponics ranged between 27.2 and $73.3 \%, 17.14$ and $51.35 \%$, and 15.73 and $48.28 \%$, respectively, for C- 1 and 18.3 and $59.6 \%, 11.42$ and $35.13 \%$, and 10.14 and $32.42 \%$, respectively, for C-2 at HRT of $1,3,5$, and 7 days as shown in Figures 3, 4, and 5. The above results show that gradual hydroponics planted with Duranta erecta showed high performance in removing $\mathrm{HB}, \mathrm{TC}$, and FC. Therefore, gradual hydroponics can be developed into a technology that can be used as alternative decentralized wastewater treatment mechanisms, especially for developing countries including Ethiopia.

The TC removal performance of this study was compared with previous studies. Yeboah and Allotey [50] reported a removal efficiency of $44.4 \%$ in treating industrial wastewater using horizontal flow hydroponics, which is less than the removal efficiency recorded in both E-1 and E-2 of this study. The removal efficiency of $60-88.7 \%$ was reported by Ottoson and Norström [32] in the treatment of municipal wastewater using horizontal flow hydroponics, which is less than the removal efficiency recorded in E-1, but greater than the removal efficiency that was recorded in E-2 of this study. Similarly, De Anda and López-López [51] reported a removal efficiency of $90.9 \%$ in the treatment of domestic wastewater using horizontal flow hydroponics, which is less than the removal efficiency recorded in E-1, but greater than the removal efficiency recorded in E-2 of this study. A better removal efficiency (99\%) was reported by Sklarz and Gross [52] and Tunçsiper and Ayaz [53] than both E-1 and E-2 in removing TC from grey and surface water using vertical gravel bed wetland planted with Juncus alpigenus and iris, respectively.

The FC removal efficiency of this study was also compared with previous studies. The removal efficiency of $90 \%$ was reported by De Anda and López-López [51] in the treatment of domestic wastewater using horizontal flow hydroponics, which is less than the removal efficiency recorded in E-1, but greater than the removal efficiency recorded in E-2 of this study. Ndulini and Sithole [54] reported a removal efficiency of $92 \%$ in the treatment of domestic wastewater using gravel bed hydroponics, which aggresses with the removal efficiency recorded in E-1, but greater than the removal efficiency recorded in E-2 of this study. Generally, this study showed that a better TC and FC removal efficiency was achieved, especially in E-1 compared with the above previous studies. A better removal efficiency (99\%) was reported by Abidi and Kallali [55] than E-1 in removing FC from domestic wastewater using vertical gravel bed wetland planted with Phragmites australis. Similar removal efficiency (84\%) was reported by Sehar and Naeem [56] in removing FC from domestic wastewater using vertical gravel bed wetland planted with Bulbophyllum reptans and Trianthema portulacastrum. 
TABLe 2: Mean influent and effluent concentration of HB, TC, and FC at different HRTs.

\begin{tabular}{|c|c|c|c|c|c|c|c|}
\hline \multirow[b]{2}{*}{ Parameters } & \multirow[b]{2}{*}{ HRT (day) } & \multirow[b]{2}{*}{ Influent } & \multicolumn{4}{|c|}{ Effluent } & \multirow[b]{2}{*}{ Ethiopian standard } \\
\hline & & & $\begin{array}{c}\mathrm{E}-1 \\
\operatorname{Avg} \pm \mathrm{SD} *\end{array}$ & $\begin{array}{c}\text { E-2 } \\
\text { Avg } \pm \text { SD }\end{array}$ & $\begin{array}{c}\text { C-1 } \\
\text { Avg } \pm \text { SD }\end{array}$ & $\begin{array}{c}\mathrm{C}-2 \\
\text { Avg } \pm \text { SD }\end{array}$ & \\
\hline $\mathrm{HB}(\mathrm{CFU} / 100 \mathrm{ml})$ & & $8.76 \pm 0.020$ & $8.34 \pm 0.004$ & $8.43 \pm 0.005$ & $8.63 \pm 0.003$ & $8.68 \pm 0.003$ & - \\
\hline TC $(\mathrm{CFU} / 100 \mathrm{ml})$ & 1 & $5.54 \pm 0.005$ & $5.17 \pm 0.021$ & $5.25 \pm 0.018$ & $5.46 \pm 0.011$ & $5.49 \pm 0.012$ & 2.6 \\
\hline $\mathrm{FC}(\mathrm{CFU} / 100 \mathrm{ml})$ & & $4.55 \pm 0.020$ & $4.25 \pm 0.047$ & $4.34 \pm 0.032$ & $4.47 \pm 0.031$ & $4.50 \pm 0.030$ & 1 \\
\hline $\mathrm{HB}(\mathrm{CFU} / 100 \mathrm{ml})$ & & $8.81 \pm 0.019$ & $8.21 \pm 0.009$ & $8.45 \pm 0.006$ & $8.55 \pm 0.004$ & $8.66 \pm 0.002$ & - \\
\hline TC (CFU/100 ml) & 3 & $5.62 \pm 0.005$ & $5.10 \pm 0.031$ & $5.23 \pm 0.015$ & $5.47 \pm 0.010$ & $5.55 \pm 0.007$ & 2.6 \\
\hline $\mathrm{FC}(\mathrm{CFU} / 100 \mathrm{ml})$ & & $4.71 \pm 0.017$ & $4.15 \pm 0.039$ & $4.31 \pm 0.040$ & $4.59 \pm 0.019$ & $4.65 \pm 0.015$ & 1 \\
\hline $\mathrm{HB}(\mathrm{CFU} / 100 \mathrm{ml})$ & & $8.82 \pm 0.010$ & $8.50 \pm 0.020$ & $8.02 \pm 0.014$ & $8.49 \pm 0.004$ & $8.60 \pm 0.003$ & - \\
\hline $\mathrm{TC}(\mathrm{CFU} / 100 \mathrm{ml})$ & 5 & $5.71 \pm 0.004$ & $4.87 \pm 0.054$ & $5.02 \pm 0.031$ & $5.54 \pm 0.009$ & $5.57 \pm 0.004$ & 2.6 \\
\hline $\mathrm{FC}(\mathrm{CFU} / 100 \mathrm{ml})$ & & $4.77 \pm 0.009$ & $3.81 \pm 0.110$ & $4.19 \pm 0.049$ & $4.61 \pm 0.018$ & $4.67 \pm 0.012$ & 1 \\
\hline $\mathrm{HB}(\mathrm{CFU} / 100 \mathrm{ml})$ & & $8.95 \pm 0.016$ & $7.06 \pm 0.098$ & $7.96 \pm 0.015$ & $8.38 \pm 0.007$ & $8.56 \pm 0.004$ & - \\
\hline TC (CFU/100 ml) & 7 & $5.86 \pm 0.002$ & $4.43 \pm 0.128$ & $4.99 \pm 0.019$ & $5.55 \pm 0.008$ & $5.68 \pm 0.007$ & 2.6 \\
\hline $\mathrm{FC}(\mathrm{CFU} / 100 \mathrm{ml})$ & & $4.96 \pm 0.008$ & $3.80 \pm 0.125$ & $4.17 \pm 0.046$ & $4.68 \pm 0.013$ & $4.79 \pm 0.011$ & 1 \\
\hline
\end{tabular}

* Standard deviation.

TABle 3: Analysis of variance (ANOVA) between different groups.

\begin{tabular}{|c|c|c|c|c|c|}
\hline No. & Parameter & Group & $P$ value & Significance $(P<0.05)$ & F-test \\
\hline \multirow{4}{*}{1} & \multirow{4}{*}{$\mathrm{HB}$} & E-1 and C-1 & 0.0111423 & Significant & 13.079828 \\
\hline & & E-2 and C-2 & 0.006203 & Significant & 16.989127 \\
\hline & & E-1 and E-2 & 0.324526 & Not significant & 1.1512903 \\
\hline & & C-1 and C-2 & 0.375934 & Not significant & 0.9141555 \\
\hline \multirow{4}{*}{2} & \multirow{4}{*}{$\mathrm{TC}$} & E-1 and C-1 & 0.000403 & Significant & 49.884600 \\
\hline & & E-2 and C-2 & 0.0010449 & Significant & 34.915459 \\
\hline & & E-1 and E-2 & 0.265333 & Not significant & 1.5086709 \\
\hline & & $\mathrm{C}-1$ and $\mathrm{C}-2$ & 0.19356 & Not significant & 2.1429313 \\
\hline \multirow{4}{*}{3} & \multirow{4}{*}{$\mathrm{FC}$} & E-1 and C-1 & 0.000976 & Significant & 35.838472 \\
\hline & & E-2 and C-2 & 0.004977 & Significant & 18.670581 \\
\hline & & E-1 and E-2 & 0.086845 & Not significant & 4.1818763 \\
\hline & & C-1 and C-2 & 0.407966 & Not significant & 0.7912619 \\
\hline
\end{tabular}

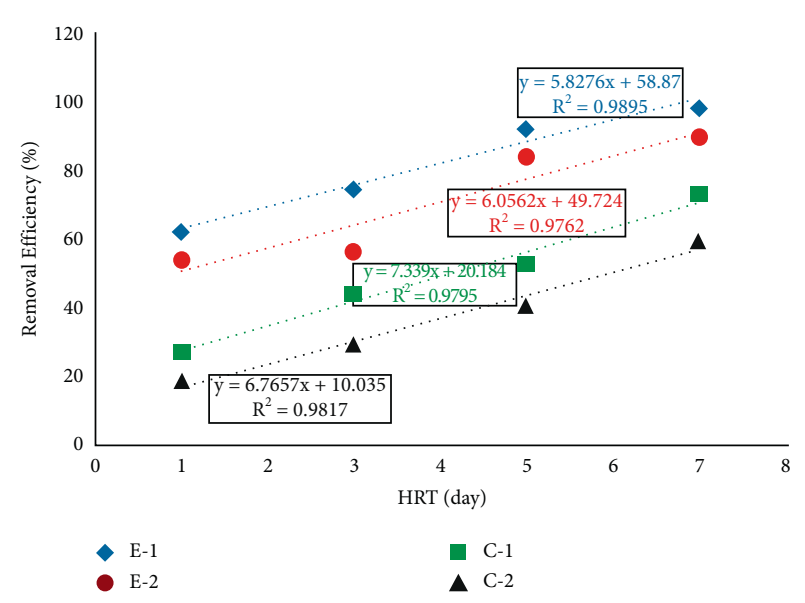

Figure 3: Regression analysis and removal efficiency of HB.

In all three parameters, E-1 showed a better bacteria removal efficiency than E-2. This might be due to the better growth of root biomass in E-1 than that in E-2. The growth of the root biomass enhances the secretion of root exudates. E-1 and E-2 also showed a better bacteria removal efficiency than their corresponding control units. Figure 6 shows a sample of the plant's roots growing on a forestry tube, which is placed on a reactor in a hydroponic system.

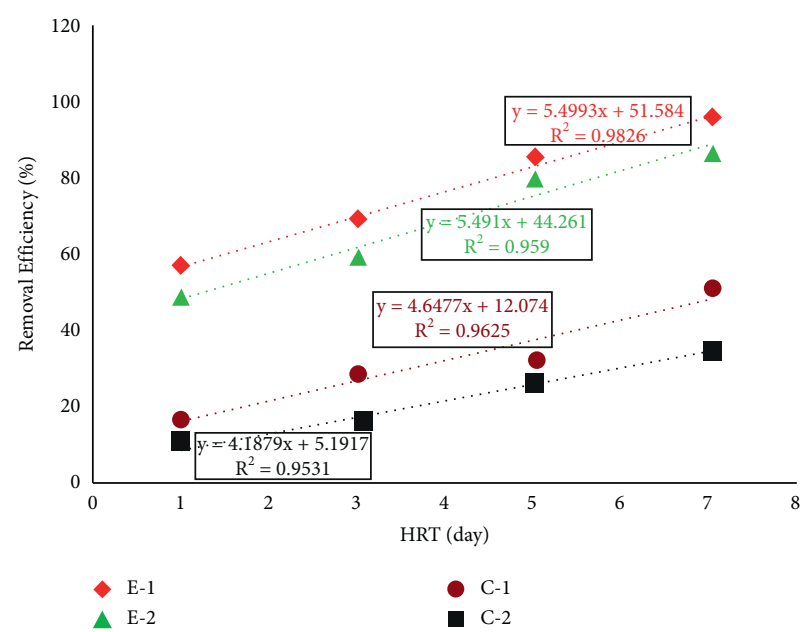

Figure 4: Regression analysis and removal efficiency of TC.

A strong linear correlation was observed in regression analysis between the applied HRTs and removal efficiency of the treatment system in removing $\mathrm{HB}, \mathrm{TC}$, and $\mathrm{FC}$ as shown in Figures 3, 4, and 5. In the removal of $\mathrm{HB}$, the regression analysis showed that $R^{2}=0.989,0.976,0.979$, and 0.981 for E-1, E-2, C-1, and C-2, respectively. In the removal of TC, 


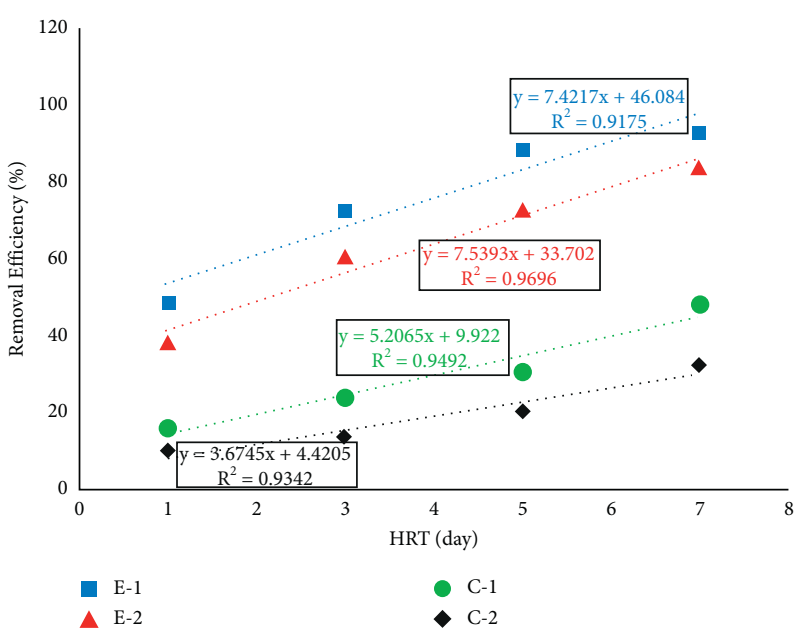

Figure 5: Regression analysis and removal efficiency of FC.

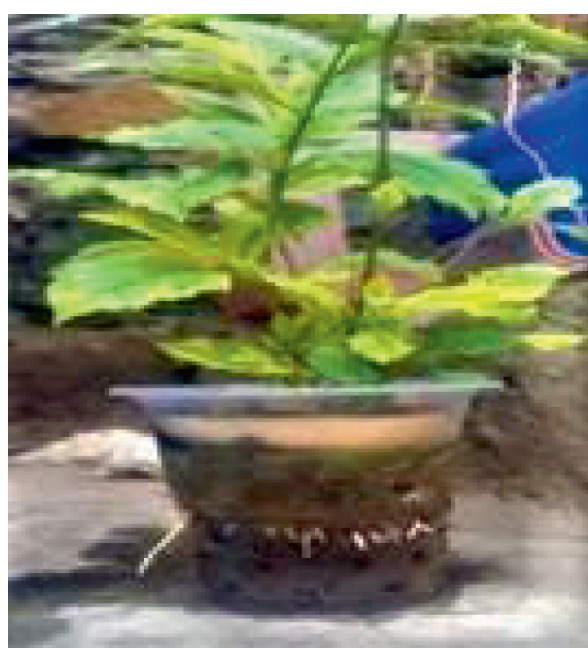

(a)

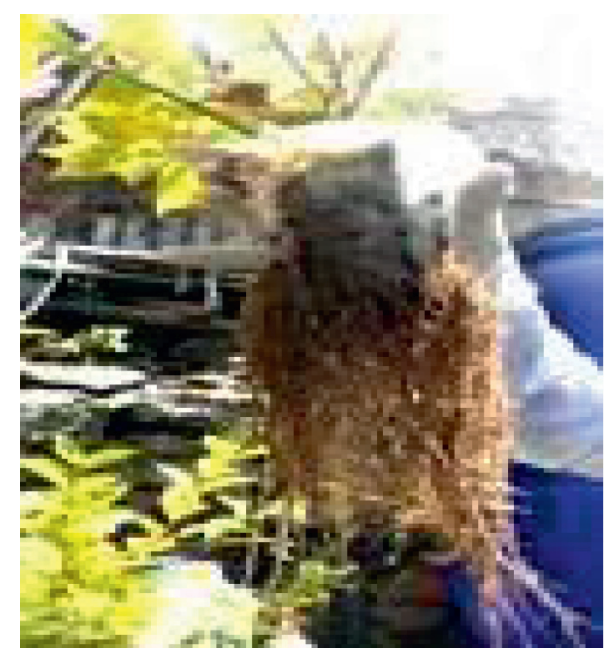

(b)

Figure 6: The growth of the plant (Duranta erecta) on the forestry tube in vertical hydroponics at two weeks of stages of acclimatization (a) and at the end of the experiment (five months after the plants were planted) (b).

the regression analysis showed that $R^{2}=0.982,0.959,0.962$, and 0.953 for E-1, E-2, C-1, and C-2, respectively. In the removal of FC regression, analysis showed that $R^{2}=0.917$, $0.969,0.949$, and 0.934 , respectively. From this, we can understand that the removal of bacteria depends on HRT, which in turn depends on HLR.

\section{Conclusion}

The effluent from the Kilinto Prison camp was treated using gradual hydroponics operated at HRT of 1, 3, 5, and 7 days. The optimum HRT in the removal of pathogens was achieved at an HRT of 7 days. The findings showed that at optimum HRT (7 days), a removal efficiency of 98.7 and $89.8 \%$ was achieved for $\mathrm{HB}$, that of 96.2 and $86.8 \%$ was achieved for TC, and that of 92.9 and $84.0 \%$ was achieved for FC using E-1 and E-2, respectively. The results obtained in this study show that the experimental units of gradual hydroponics planted with Duranta erecta significantly removed $\mathrm{HB}, \mathrm{TC}$, and $\mathrm{FC}$ from domestic wastewater. Therefore, scaling up of this pilot gradual hydroponics has a great advantage for developing countries such as Ethiopia.

\section{Data Availability}

All data are available in this study.

\section{Conflicts of Interest}

The authors declare that they have no conflicts of interest.

\section{Authors' Contributions}

Solomon Tibebu (first author) wrote up the manuscript and conducted experiments in the field. Abebe Worku (second author) supervised the experiment and wrote, structured, read, edited, and approved the final manuscript. Kenatu Angassa (third author) read, edited, and approved the final 
manuscript. All the authors made significant contributions to the document and agree to its publication.

\section{Acknowledgments}

The authors thank Addis Ababa Science and Technology University (AASTU) and the Ethiopian Road Authority (ERA) for their financial support.

\section{References}

[1] D. Mara, Domestic Wastewater Treatment in Developing Countries, Routledge, London, UK, 2013.

[2] M. Eriksson and J. Sigvant, Causes and impact of surface water pollution in Addis Ababa, Ethiopia, Jonathan University, Master Programme in Environmental and Water Engineering, Uppsala University, Uppsala, Sweden, 2019.

[3] Y. Anteneh, G. Zeleke, and E. Gebremariam, "Valuing the water supply: ecosystem-based potable water supply management for the legedadie-dire catchments, central Ethiopia," Ecological Processes, vol. 8, no. 1, p. 9, 2019.

[4] K. K. Al-Bayatti, K. H. Al-Arajy, and S. H. Al-Nuaemy, "Bacteriological and physicochemical studies on Tigris river near the water purification stations within Baghdad province," Journal of Environmental and Public Health, vol. 2012, Article ID 695253, 8 pages, 2012.

[5] D. Sharma and A. Kansal, "Water quality analysis of river Yamuna using water quality index in the national capital territory, India (2000-2009)," Applied Water Science, vol. 1, no. 3, pp. 147-157, 2011.

[6] M. Camara, N. R. Jamil, and A. F. B. Abdullah, "Impact of land uses on water quality in Malaysia: a review," Ecological Processes, vol. 8, no. 1, pp. 1-10, 2019.

[7] K. Asnake, H. Worku, and M. Argaw, "Assessing the impact of watershed land use on Kebena river water quality in Addis Ababa, Ethiopia," Environmental Systems Research, vol. 10, no. 1, pp. 1-14, 2021.

[8] A. Gowda, S. Srikantaswamy, K. Rajasekhara Reddy, M. R. Abhilash, D. Shiva Kumar, and K. Jagadish, "Impact of anthropological activities on the water quality of Cauvery river, Karnataka, India," International Journal of Research Science Innovation, vol. 3, pp. 6-15, 2016.

[9] M. Getachew, W. Legesse Mulat, S. Tiku Mereta, G. Sahilu Gebrie, and M. Kelly-Quinn, "Challenges for water quality protection in the greater metropolitan area of Addis Ababa and the upper awash basin, Ethiopia-time to take stock," Environmental Reviews, vol. 29, 2020, (ja).

[10] E. Teshome Mekonnen, S. Abate Temesgen, Wujumie, D. Xu, and $\mathrm{Z}$. $\mathrm{Wu}$, "An overview of water pollution status in Ethiopia with a particular emphasis on Akaki river: a review," vol. 3, 2020.

[11] T. H. Debela, A. Beyene, E. Tesfahun, A. Getaneh, A. Gize, and Z. Mekonnen, "Fecal contamination of soil and water in subSaharan Africa cities: the case of Addis Ababa, Ethiopia," Ecohydrology \& Hydrobiology, vol. 18, no. 2, pp. 225-230, 2018.

[12] H. Yohannes and E. Elias, "Contamination of rivers and water reservoirs in and around Addis Ababa city and actions to combat it," Environment Pollution Climate Change, vol. 1, no. 116, p. 8, 2017.

[13] P. G. Nembrini and C. I. D. L. Croix-Rouge, "Water, sanitation, hygiene and habitat in prisons," International Committee of the Red Cross, 2005.

[14] M. Aschale, Y. Sileshi, M. Kelly-Quinn, and D. Hailu, "Multivariate analysis of potentially toxic elements in surface waters in Ethiopia," Applied Water Science, vol. 11, no. 5, pp. 1-13, 2021.

[15] A. Mekonen, "Suitability assessment of little Akaki river for irrigation," M. Sc. thesis, Department of Chemical Engineering, Addis Ababa University, Addis Ababa, Ethiopia, 2007.

[16] A. Mekonnen, S. Leta, and K. N. Njau, "Wastewater treatment performance efficiency of constructed wetlands in African countries: a review," Water Science and Technology, vol. 71, no. 1, pp. 1-8, 2015.

[17] A. W. T. K. Sisay Derso Mengesha, K. Tesfaye Teklu, M. Gizaw et al., Pollution Status of Akaki River and its Contamination Effect on Surrounding Environment and Agricultural Products: Ethiopian Public Health Institute, Addis Ababa, Ethiopia, 2017.

[18] K. E. Shannon, D. Y. Lee, J. T. Trevors, and L. A. Beaudette, "Application of real-time quantitative PCR for the detection of selected bacterial pathogens during municipal wastewater treatment," Science of the Total Environment, vol. 382, no. 1, pp. 121-129, 2007.

[19] M. Von Sperling, Wastewater Characteristics, Treatment and Disposal, IWA Publishing London, London, UK, 2007.

[20] A. Rompré, P. Servais, J. Baudart, M. R. de-Roubin, and P. Laurent, "Detection and enumeration of coliforms in drinking water: current methods and emerging approaches," Journal of Microbiological Methods, vol. 49, no. 1, pp. 31-54, 2002.

[21] A. M. Motlagh and Z. Yang, "Detection and occurrence of indicator organisms and pathogens," Water Environment Research, vol. 91, no. 10, pp. 1402-1408, 2019.

[22] M. L. Tortorello, "Indicator organisms for safety and quality—uses and methods for detection: minireview," Journal of AOAC International, vol. 86, no. 6, pp. 1208-1217, 2003.

[23] A. Angelakis and B. Durham, "Water recycling and reuse in EUREAU countries: trends and challenges," Desalination, vol. 218, no. 1-3, pp. 3-12, 2008.

[24] S. Naidoo and A. O. Olaniran, "Treated wastewater effluent as a source of microbial pollution of surface water resources," International Journal of Environmental Research and Public Health, vol. 11, no. 1, pp. 249-270, 2014.

[25] A. Worku, N. Tefera, H. Kloos, and S. Benor, "Bioremediation of brewery wastewater using hydroponics planted with vetiver grass in Addis Ababa, Ethiopia," Bioresources and Bioprocessing, vol. 5, no. 1, p. 39, 2018.

[26] M. J. Shahid, A. A. AL-surhanee, F. Kouadri et al., "Role of microorganisms in the remediation of wastewater in floating treatment wetlands: a review," Sustainability, vol. 12, no. 14, p. 5559, 2020.

[27] S. Arjina and D. Bruce, "Oklahoma cooperative extension service HLA-6442," Technical report, Oklahoma State University, Stillwater, OK, USA, 2010.

[28] A. Richa, "Recent advances and perspectives in the treatment of hydroponic wastewater: a review," Reviews in Environmental Science and Bio/Technology, vol. 19, pp. 1-22, 2020.

[29] M. D. Sardare and S. V. Admane, "A review on plant without soil-hydroponics," International Journal of Research in Engineering and Technology, vol. 2, no. 03, pp. 299-304, 2013.

[30] O. Mokuolu, S. Olokoba, S. Aremu, and O. Olanlokun, "Fish pond wastewater hydroponic treatment potential of Citrullus colocynthis," Journal of Research in Forestry, Wildlife and Environment, vol. 11, no. 1, pp. 118-126, 2019.

[31] N. Oyama, Hydroponics System for Wastewater Treatment and Reuse in Horticulture, Murdoch University, Perth, Australia, 2008. 
[32] J. Ottoson, A. Norström, and G. Dalhammar, "Removal of micro-organisms in a small-scale hydroponics wastewater treatment system," Letters in Applied Microbiology, vol. 40, no. 6, pp. 443-447, 2005.

[33] K. Angassa, S. Leta, W. Mulat, H. Kloos, and E. Meers, "Organic matter and nutrient removal performance of horizontal subsurface flow constructed wetlands planted with Phragmite karka and Vetiveria zizanioide for treating municipal wastewater," Environmental Processes, vol. 5, no. 1, pp. 115-130, 2018.

[34] A. Stefanakis, C. S. Akratos, and V. A. Tsihrintzis, Vertical Flow Constructed Wetlands: Eco-Engineering Systems for Wastewater and Sludge Treatment, Newnes, London, UK, 2014.

[35] S. J. Conn, B. Hocking, M. Dayod et al., "Protocol: optimising hydroponic growth systems for nutritional and physiological analysis of Arabidopsis thaliana and other plants," Plant Methods, vol. 9, no. 1, p. 4, 2013.

[36] A. I. Okunlola, "The effects of cutting types and length on rooting of Duranta Repens in the nursery," Global Journal of Human Social Science Geography Geo-Science Environment Disaster Management, vol. 13, no. 3, pp. 1-5, 2013.

[37] R. Regassa, "Useful plant species diversity in homegardens and its contribution to household food security in Hawassa city, Ethiopia," African Journal of Plant Science, vol. 10, no. 10, pp. 211-233, 2016.

[38] J. K. Francis, "Duranta erecta L. golden dewdrop," Wildland Shrubs of the United States and Its Territories: Thamnic Descriptions, vol. 299, 2004.

[39] M. Haddad, N. Mizyed, and M. Masoud, "Evaluation of gradual hydroponic system for decentralized wastewater treatment and reuse in rural areas of palestine," International Journal of Agricultural and Biological Engineering, vol. 5, no. 4, pp. 47-53, 2012.

[40] K. Angassa, S. Leta, W. Mulat, H. Kloos, and E. Meers, "Evaluation of pilot-scale constructed wetlands with Phragmites karka for phytoremediation of municipal wastewater and biomass production in Ethiopia," Environmental Processes, vol. 6, no. 1, pp. 65-84, 2019.

[41] K. Prayong, "Efficiency of wastewater treatment with hydroponics," ARPN Journal of Agricultural and Biological Science, vol. 8, 2020, (Internet).

[42] E. W. Rice, R. B. Baird, A. D. Eaton, and L. S. Clesceri, Standard Methods for the Examination of Water and Wastewater, vol. 10, American Public Health Association, Washington, DC, 2012.

[43] M. Seo, H. Lee, and Y. Kim, "Relationship between coliform bacteria and water quality factors at weir stations in the Nakdong river, South Korea," Water, vol. 11, no. 6, p. 1171, 2019.

[44] D. L. Bohra, V. Modasiya, and C. K. Bahura, "Distribution of coliform bacteria in waste water," Microbiology Research, vol. 3, no. 1, p. e2, 2012.

[45] N. J. Ashbolt, "Microbial contamination of drinking water and disease outcomes in developing regions," Toxicology, vol. 198, no. 1-3, pp. 229-238, 2004.

[46] G. Cissé, "Food-borne and water-borne diseases under climate change in low-and middle-income countries: further efforts needed for reducing environmental health exposure risks," Acta Tropica, vol. 194, pp. 181-188, 2019.

[47] S. I. Alexandros and C. S. Akratos, "Removal of pathogenic bacteria in constructed wetlands: mechanisms and efficiency," in Phytoremediation, pp. 327-346, Springer, Berlin, Germany, 2016.
[48] L. Sartori, S. Canobbio, R. Fornaroli, R. Cabrini, F. Marazzi, and V. Mezzanotte, "COD, nutrient removal and disinfection efficiency of a combined subsurface and surface flow constructed wetland: a case study," International Journal of Phytoremediation, vol. 18, no. 4, pp. 416-422, 2016.

[49] C. S. C. Calheiros, S. I. A. Pereira, H. Brix, A. O. S. S. Rangel, and P. M. L. Castro, "Assessment of culturable bacterial endophytic communities colonizing Canna flaccida inhabiting a wastewater treatment constructed wetland," Ecological Engineering, vol. 98, pp. 418-426, 2017.

[50] S. A. Yeboah, A. Allotey, and E. Biney, "Purification of industrial wastewater with vetiver grasses (Vetiveria zizanioides): the case of food and beverages wastewater in Ghana," Asian Journal of Basic and Applied Sciences, vol. 2, 2015.

[51] J. De Anda, A. López-López, E. Villegas-García, and K. Valdivia-Aviña, "High-strength domestic wastewater treatment and reuse with onsite passive methods," Water, vol. 10, no. 2, p. 99, 2018.

[52] M. Sklarz, A. Gross, A. Yakirevich, and M. Soares, "A recirculating vertical flow constructed wetland for the treatment of domestic wastewater," Desalination, vol. 246, no. 1-3, pp. 617-624, 2009.

[53] B. Tunçsiper, S. Ç. Ayaz, and L. Akça, "Coliform bacteria removal from septic wastewater in a pilot-scale combined constructed wetland system," Environmental Engineering \& Management Journal (EEMJ), vol. 11, no. 10, 2012.

[54] S. Ndulini, G. Sithole, and M. Mthembu, "Investigation of nutrients and faecal coliforms removal in wastewater using a hydroponic system," Physics and Chemistry of the Earth, Parts A/B/C.vol. 106, pp. 68-72, 2018.

[55] S. Abidi, H. Kallali, N. Jedidi, O. Bouzaiane, and A. Hassen, "Comparative pilot study of the performances of two constructed wetland wastewater treatment hybrid systems," Desalination, vol. 246, no. 1-3, pp. 370-377, 2009.

[56] S. Ehar, S. Naeem, I. Perveen, N. Ali, and S. Ahmed, "A comparative study of macrophytes influence on wastewater treatment through subsurface flow hybrid constructed wetland," Ecological Engineering, vol. 81, pp. 62-69, 2015. 